\title{
Soluble and bacteriophage T4 displayed gp41 mutant proteins as HIV-1 vaccine candidates
}

\author{
G Gao ${ }^{1 *}$, KK Peachman², L Wieczorek², V Polonis ${ }^{2}, C^{2}$ Alving², M Rao², VB Rao ${ }^{1}$ \\ From AIDS Vaccine 2012 \\ Boston, MA, USA. 9-12 September 2012
}

\section{Background}

HIV-1 envelope protein gp41 is a very attractive vaccine target as its epitopes are recognized by three broadly neutralizing antibodies. However, the extreme hydrophobicity and very transient exposure of neutralizing epitopes during infection has hampered its usage in HIV-1 vaccine development. Our goal is to design a soluble trimeric gp41 vaccine stabilized as a pre-hairpin intermediate.

\section{Methods}

A gp41AVERY-minus recombinant was constructed, which contained both gp41 ecto-domain and cytodomain, while the immunodominant AVERY region was deleted to reduce elicitation of non-neutralizing antibodies. Another protein, gp41-5M, was constructed by introducing 5 point mutations to gp41AVERY-minus, at the exposed hydrophobic residues of the trimeric coiled coil region, in order to destabilize the interaction between HR1 and HR2 helices and therefore mimic the gp41 prehairpin intermediate. A 'foldon' structural tag was fused at the C-terminus of gp41-5M to facilitate trimer formation, and phage T4 small outer capsid (Soc) protein was fused at the N-terminus for arraying gp41 on T4 capsids. The ability of purified Soc-gp41-5M proteins to inhibit 4E10 and 2F5 neutralizing activity was tested in the TZM-bl assay. Immunization experiments were performed in rabbits using soluble as well as T4 displayed gp41 antigens to determine their immunogenicity.

\section{Results}

gp41 mutant proteins were over-expressed in E. coli and purified in soluble form following denaturation, renaturation, and Histrap affinity chromatography. The Socgp41-5M protein formed trimers and other oligomers,

${ }^{1}$ The Catholic University of America, Washington, DC, USA

Full list of author information is available at the end of the article and effectively competed with native epitopes present on HIV-1 virus for binding to 4E10 and 2F5 antibodies in the TZM-bl assay. The sera from all immunized rabbits showed binding antibodies to gp 41 while some also showed neutralizing antibodies.

\section{Conclusion}

Soluble near full-length trimeric gp41 immunogens can be produced by interfering with the HR1-HR2 interactions while retaining the $4 \mathrm{E} 10$ and 2F5 binding epitope conformations. These proteins might be good vaccine candidates to elicit broadly neutralizing antibodies.

\section{Author details}

${ }^{1}$ The Catholic University of America, Washington, DC, USA. ${ }^{2}$ USMHRP, Walter Reed Army Institute of Research, Silver Spring, MD, USA.

Published: 13 September 2012

doi:10.1186/1742-4690-9-S2-P10

Cite this article as: Gao et al:: Soluble and bacteriophage T4 displayed gp41 mutant proteins as HIV-1 vaccine candidates. Retrovirology 20129 (Suppl 2):P10.

Submit your next manuscript to BioMed Central and take full advantage of:

- Convenient online submission

- Thorough peer review

- No space constraints or color figure charges

- Immediate publication on acceptance

- Inclusion in PubMed, CAS, Scopus and Google Scholar

- Research which is freely available for redistribution
@ 2012 Gao et al; licensee BioMed Central Ltd. This is an Open Access article distributed under the terms of the Creative Commons Attribution License (http://creativecommons.org/licenses/by/2.0), which permits unrestricted use, distribution, and reproduction in any medium, provided the original work is properly cited. 